\title{
Досвід використання дексмедетомідіну у відділенні реанімації та інтенсивної терапії кардіохірургічного профілю
}

\author{
Лісічкіна О. М., Бойко С. М., Труба Я. П., Лазоришинець В. В. \\ ДУ “Національний інститут серцево-судинної хірургії імені М. М. Амосова НАМН” (Київ)
}

\begin{abstract}
У статті представлено досвід використання дексмедетомідіну для седації пацієнтів у реанімаційних відділеннях кардіохірургічного профілю та проведено порівняльний аналіз застосування цього препарату та пропофолу в пацієнтів дитячого віку після хірургічної корекції різних вроджених вад серця.
\end{abstract}

Ключові слова: седація, дексмедетомідін, альфа2-агоністи.

Седація пацієнтів, які знаходяться у відділеннях реанімації та інтенсивної терапії після кардіохірургічних втручань, залишається однією з найактуальніших проблем. У той же час складність даного питання полягає у тому, що препарати для седації, доступні в нашій країні, суттєво впливають на гемодинаміку пацієнтів, тому не можуть використовуватися в кардіохірургічних реанімаціях рутинно. Ідеальний седативний препарат повинен мати такі властивості: здатність швидко викликати сон, близький до фізіологічного, швидкий початок дії та коротку тривалість, відсутність активних метаболітів, відсутність кумуляції у пацієнтів із нирковою або печінковою недостатністю, мінімальний вплив на серцево-судинну та дихальну системи, сумісність 3 іншими медикаментами. Постійній інфузії бензодіазепінів або опіатів властиві погана контрольованість (їх дія триває після закінчення інфузії ще декілька годин), вивільнення активних метаболітів, що кумулюються, побічні ефекти у вигляді пригнічення гемодинаміки та дихання. Останнім часом з'явилося багато публікацій щодо дексмедетомідіну - нового препарату із седативними, анксіолітичними та аналгетичними властивостями - та його застосування у відділеннях інтенсивної терапії у пацієнтів різних вікових груп [1].

Дексмедетомідін був зареєстрований у США в 1999 році (Precedex®; Hospira, LakeForrest, IL, USA) як препарат для довготривалої седації дорослих пацієнтів, які знаходяться на ШВЛ, у відділеннях реанімації та інтенсивної терапії. У 2001 році частота призначення дексмедетомідіну в кардіохірургічних реанімаціях США становила 18,8\%, а до 2007 року підвищилася до 49,4\%. У 2008 році препарат отримав дозвіл на використання для седації пацієнтів на спонтанному диханні при хірургічних втручаннях та інших маніпуляціях. Таким чином, до 2013 року дексмедетомідін став у США препаратом, що найбільш часто використовується для седації у BAIT [3]. На даний момент використання дексмедетомідіну в дитячій практиці ще знаходиться на етапі досліджень, але вже існує значна кількість публікацій щодо успішної седації за допомогою цього препарату в реанімаційних відділеннях, при виконанні КТ або МРТ, як компонента для анестезії тощо [9].

Дексмедетомідін - це високоселективний альфа2агоніст з індексом специфічності альфа2:альфа1 1600:1. В основі седативного ефекту цього препарату, що нагадує фізіологічний сон, знаходиться активація підтипу А альфа2-адренорецепторів у блакитному ядрі (locus coeruleus) стовбуру головного мозку. Механізм седативної дії дексмедетомідіну принципово відрізняється від фармакодинаміки бензодіазепінів та пропофолу, в основі якої лежить вплив на ГАМК-ергічні нейрони. На відміну від останніх, агоністи альфа2-адренорецепторів не пригнічують нейрони центральної нервової системи, а знижують активність, при цьому зберігаючи реактивність нейронів блакитного ядра стовбура головного мозку. Пацієнти, що отримують постійну інфузію дексмедетомідіну, легко просинаються і здатні до взаємодії з медичним персоналом. Також препарати цієї групи не пригнічують функцію дихального центру. Побічні ефекти альфа2-агоністів, такі як брадикардія та транзиторна артеріальна гіпертензія (і гіпотензія, що реалізується шляхом симпатолітичних ефектів препаратів), зумовлені дією альфа2-адренорецепторів дорзальних мотонейронів спинного мозку і тому не пов'язані із седативною дією препаратів.

Мета дослідження - вивчити ефективність використання дексмедетомідіну для седації пацієнтів у дитячих реанімаційних відділеннях кардіохірургічного профілю та провести аналіз і порівняння гемодинамічних та інших ефектів дексмедетомідіну та пропофолу.

Матеріали та методи. У процесі дослідження вивчалися клінічні показники у 34 пацієнтів дитячого віку, що проходили лікування у відділенні реанімації та інтенсивної терапії вроджених вад серця Національного інституту серцево-судинної хірургії імені М. М. Амосова НАМН після хірургічної корекції ВВС за період 


\section{Таблиця 1}

Основні характеристики досліджуваних груп пацієнтів $(n=34)$

\begin{tabular}{|c|c|c|c|c|c|c|}
\hline \multicolumn{2}{|c|}{ Характеристики } & \multicolumn{2}{|c|}{$\begin{array}{c}\text { Дексмеде- } \\
\text { томідін (n=18) }\end{array}$} & \multicolumn{2}{|c|}{$\begin{array}{c}\text { Пропо- } \\
\text { фол }(n=16)\end{array}$} & p \\
\hline \multicolumn{2}{|l|}{ Вік } & \multicolumn{2}{|c|}{ 5,86 $\pm 2,93$ міс. } & \multicolumn{2}{|c|}{ 6,18 $\pm 2,06$ міс. } & 0,001 \\
\hline \multirow{2}{*}{ Стать } & Чол. & 6 & $33 \%$ & 8 & $50 \%$ & 0,001 \\
\hline & Жін. & 12 & $67 \%$ & 8 & $50 \%$ & 0,001 \\
\hline & 5 & $27,8 \%$ & 3 & $18,75 \%$ & $<0,001$ \\
\hline \multicolumn{2}{|c|}{ VSD з ВГЛА } & 3 & $16,7 \%$ & 4 & $25 \%$ & $<0,001$ \\
\hline \multicolumn{2}{|c|}{ VSD 3 SP } & & & 2 & $12,5 \%$ & $<0,001$ \\
\hline \multicolumn{2}{|c|}{ AV-комунікація } & 3 & $17 \%$ & 1 & $6,25 \%$ & $<0,001$ \\
\hline \multicolumn{2}{|c|}{ ВАП } & 1 & $5,5 \%$ & 2 & $12,5 \%$ & $<0,001$ \\
\hline \multicolumn{2}{|l|}{ ASD II } & 4 & $22,2 \%$ & 2 & $12,5 \%$ & $<0,001$ \\
\hline \multicolumn{2}{|l|}{ ТФ } & & & 2 & $12,5 \%$ & $<0,001$ \\
\hline \multicolumn{2}{|c|}{ Коарктація аорти } & 1 & $5,5 \%$ & & & $<0,001$ \\
\hline \multicolumn{2}{|c|}{ ЧАДЛВ } & 1 & $5,5 \%$ & & & $<0,001$ \\
\hline \multicolumn{2}{|c|}{$\begin{array}{l}\text { Діти із синдромом } \\
\text { Дауна }\end{array}$} & 4 & $22,2 \%$ & 3 & $18,75 \%$ & \\
\hline \multicolumn{2}{|c|}{ Час ШВЛ (години) } & \multicolumn{2}{|c|}{$12,1 \pm 5,8$} & \multicolumn{2}{|c|}{$10,4 \pm 6,2$} & 0,01 \\
\hline \multicolumn{2}{|c|}{$\begin{array}{l}\text { Час знаходження у } \\
\text { ВІТ (доби) }\end{array}$} & \multicolumn{2}{|c|}{$6,8 \pm 3,0$} & \multicolumn{2}{|c|}{$7,1 \pm 2,4$} & 0,01 \\
\hline
\end{tabular}

з червня 2016 року по березень 2017 року. Серед пацієнтів, які ввійшли в дослідження, було 14 хлопчиків $(41,17 \%)$ та 20 дівчаток $(58,83 \%)$ віком $6 \pm 4,5$ міс., 3 масою тіла 6,52 $\pm 3,12$ кг. Дослідження проводилось у пацієнтів, що знаходилися у ВАIT до 10 діб з різними вродженими вадами серця, серед яких: VSD - 8 дітей (24\%), VSD з ВГЛА - 7 дітей (20,5\%), VSD з SP - 2 дітей $(5,8 \%), \mathrm{AV}$-комунікація - 4 дітей $(11,7 \%)$, ВАП 3 дітей $(8,8 \%)$, ASD II - 6 дітей (17,6\%), ТФ - 2 дітей $(5,8 \%)$, коарктація аорти - 1 дитина $(2,9 \%)$, ЧАДЛВ 1 дитина (2,9\%). Пацієнти були поділені на дві групи: до першої групи ввійшли діти, що отримували пропофол у середній дозі 1-2 мг/кг/год. в якості седативного препарату, до другої - ті, що отримували для седації дексмедетомідін протягом $14 \pm 5$ годин у середній дозі 0,66 $\pm 0,26$ мкг Кгг/год. (табл. 1).

Результати та обговорення. Виконувалося дослідження та порівняння показників артеріального тиску, частоти серцевих скорочень та ефективності седації пацієнтів.

Стан фізіологічного сну або помірної седації в обох групах реєструвався у 94\% часу. Оцінка ступеня седації здійснювалася за шкалою Rass і становила в першій групі $-3,3 \pm 0,8$, у другій $-1,5 \pm 1,0$, шо відповідає стану від помірної до середньої седації з можливістю реакції пацієнта на звуковий подразник (голос).

Систолічний артеріальний тиск у групі дексмедетомідіну знижувався з $88 \pm 14$ мм рт. ст. до $85 \pm 13$ мм рт. ст. $(\mathrm{p}=0,05)$, частота серцевих скорочень (ЧСС) - 3 $151 \pm 20 /$ хв. до $109 \pm 12 /$ хв. $(\mathrm{p}<0,01)$, а частота дихання залишалася незмінною. У порівнянні з базовими по-

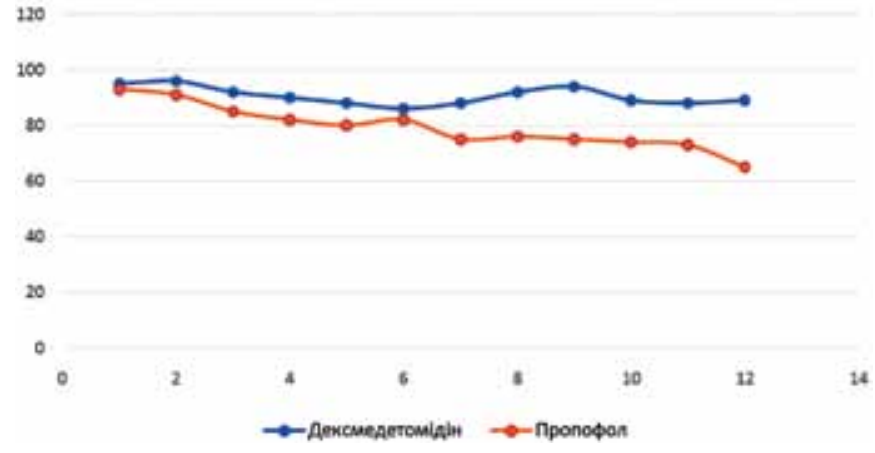

Рис.1. Динаміка систолічного артеріального тиску

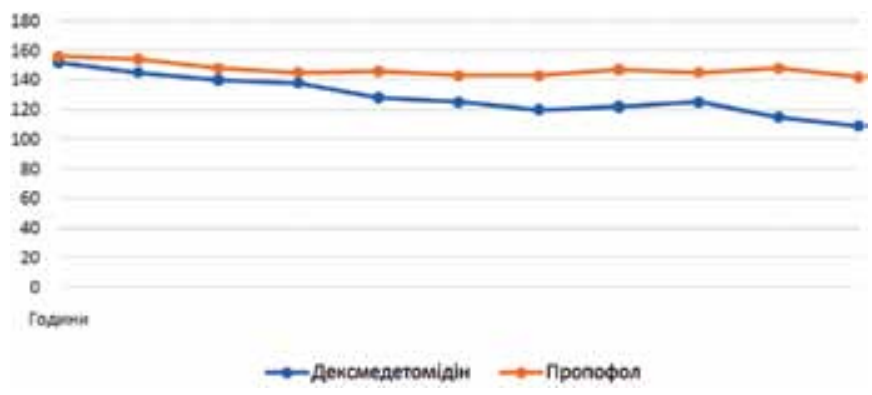

Рис.2. Динаміка частоти сериевих скорочень

казниками газів крові 3 найбільшими їх коливання-

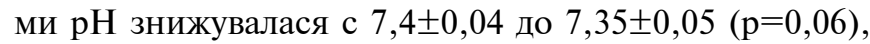
pO2 - $394 \pm 32$ мм рт. ст. до $69 \pm 21$ мм рт. ст. $(\mathrm{p}=0,05)$ та рСО2 підвищувалася з $45 \pm 7$ мм рт. ст. до $51 \pm 9$ мм рт. ст. $(\mathrm{p}=0,01)$.

У групі пропофолу частіше реєструвалося зниження артеріального тиску порівняно з групою дексмедетомідіну ( $89 \pm 7$ мм рт. ст. до $76 \pm 8$ мм рт. ст. $(\mathrm{p}=0,05)$, частота серцевих скорочень змінювалася менш значно (з $152 \pm 14 /$ хв. до $145 \pm 13 /$ x. $(\mathrm{p}=0,05)$. Також пропофол має більший вплив на частоту дихання: відмічалося зниження ЧД з $42 \pm 5 /$ хв. до $35 \pm 4 /$ хв., що супроводжувалося дозозалежною зміною характеру дихання на більш поверхневе та зниженням SpO2, що потребувало додаткової подачі кисню. Динаміка газів крові була

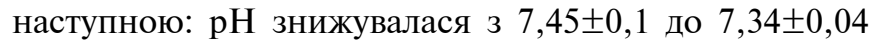
$(\mathrm{p}=0,05), \mathrm{pO} 2-396 \pm 28$ мм рт. ст. до $65 \pm 26$ мм рт. ст. $(\mathrm{p}=0,05), \mathrm{pCO} 2$ підвищувалася $344 \pm 5$ мм рт.ст. до $55 \pm 4$ мм рт. ст. $(\mathrm{p}=0,05)$ (рис. 1,2$)$.

Висновки. Проведене нами дослідження виявило достатню ефективність і безпечність застосування дексмедетомідіну у дітей, що знаходяться на лікуванні у відділенні реанімації та інтенсивної терапії після різних кардіохірургічних втручань. Відсутність пригнічення функції дихальної системи робить його перспективним препаратом для седації пацієнтів дитячого віку порівняно з традиційними препаратами. 


\section{Література}

1. Clinical Pharmacokinetics and Pharmacodynamics of Dexmedetomidine / Maud A. S. Weerink, Michel M. R. F. Struys, Laura N. Hannivoort et al. // Clinical Pharmacocinetics. - 2017. - Vol. 56 (8). P. 893-913.

2. Козлов И. А., Кричевский Л. А. Дексмедетомидин для седации кардиохирургических больных // Патология кровообращения и кардиохирургия. - 2014. - Вып. 3, том 18. - C. 67-75.

3. Marcia L. Buck, Pharm D. Dexmedetomidine Use in Pediatric Intensive Care and Procedural Sedation // Journal of Pediatric Pharmacology and Therapeutics. 2010 Jan-Mar. - Vol. 15 (1). - P. 17-29.

4. Incidence of bradycardia in pediatric patients receiving dexmedetomidine anesthesia: a meta-analysis / Maowei Gong, Yuanyuan Man, Qiang Fu // International Journal of Clinical Pharmacy. - 2017 Feb. - Vol. 39, Issue 1. - P. 139-147.
5. Alpha-2 agonists for long-term sedation during mechanical ventilation in critically ill patients / Chen K., Lu Z., Xin Y. C. et al. // Cochrane Database of Systematic Reviews. - 2015, Issue 1. - Cd010269.

6. Phan H., Nahata M.C. Clinical uses of dexmedetomidine in pediatric patients // Paediatric Drugs. - 2008. - Vol. 10 (1). - P. 49-69.

7. Safety and Effectiveness of Dexmedetomidine in the Pediatric Intensive Care Unit (SAD-PICU) / Laura Carney, Jennifer Kendrick, Roxane Carr // The Canadian Journal of Hospital Pharmacy. - 2013 Jan-Feb. - Vol. 66 (1). - P. 21-27.

8. Buck M. L., Willson D. F. Use of dexmedetomidine in the pediatric intensive care unit // Pharmacotherapy. - 2008. Vol. 28 (1). - P. 51-57.

9. Does dexmedetomidine cause less airway collapse than propofol when used for deep sedation? / Watt S., Sabouri S., Hegazy R. et al. // J Clin Anesth. - 2016 Dec. - Vol. 35. P. $259-267$.

\title{
The Experience of Using of Dexmedetomidine for Sedation in Cardiac Intensive Care Units
}

\author{
Lisichkina O. N., Boyko S. M., Truba Ya. P., Lazoryshynets V. V. \\ National M. M. Amosov Institute of Cardiovascular Surgery National Academy of Medical Sciences of Ukraine (Kyiv)
}

The article presents the experience of using of dexmedetomidine for sedation in cardiac intensive care units. Comparative analysis of using of dexmedetomidine and propofol in children after surgical treatment of congenital heart disease is conducted.

Key words: sedation, dexmedetomidine, alpha2-agonists.

\section{Опыт использования дексмедетомидина в отделении реанимации и интенсивной терапии кардиохирургического профиля}

\author{
Лисичкина О. Н., Бойко С. Н., Труба Я. П., Лазоришинец В. В. \\ ГУ «Национальный институт сердечно-сосудистой хирургии имени Н. М. Амосова НАМН» (Киев)
}

В статье представлен опыт использования дексмедетомидина для седации пациентов в реанимационных отделениях кардиохирургического профиля. Проведен анализ использования дексмедетомидина по сравнению с пропофолом у пациентов детского возраста после хирургической коррекции врожденных пороков сердца.

Ключевые слова: седация, дексмедетомидин, альфа2-агонисты. 